34. Stubbs WA, Alberti KGMM 1980 The lung, whole-body metabolism and disease. In: Whelan J (ed) Metabolic Activity of the Lung. Excerpta Medica, Amsterdam, pp 351-372

35. Post M, Barsoumian A, Smith BT 1986 The cellular mechanism of glucocorticoid acceleration of fetal lung maturation. J Biol Chem 261:2179-2184

36. Moxley MA, Longmore WJ 1977 Effect of experimental diabetes and insulin on lipid metabolism in the isolated perfused rat lung. Biochim Biophys Acta 488:218-224

37. Engle MJ, Langan SM, Sanders RL 1983 Effects of insulin and hyperglycemia on surfactant phospholipid synthesis in organotypic type II cells. Biochim Biophys Acta 753:6-13

38. Sugahara K, Friedenberg GR, Mason RJ 1984 Insulin binding and effects on glucose and transepithelial transport by alveolar type Il cells. Am J Physiol 247:C472-C477

39. Fricke RF, Longmore WJ 1979 Effects of insulin and diabetes on 2-deoxy-dglucose uptake by the isolated perfused rat lung. J Biol Chem 254:50925098

\title{
Announcement
}

\section{Annual Meeting of the European Society for Pediatric Research 1991}

The European Society for Pediatric Research (ESPR) will hold its next meeting in Zürich, Switzerland, September 1-4, 1991. The European Society of Pediatric Allergy and Clinical Immunology and the European Society of Magnetic Resonance in Neuropediatrics will join the ESPR. Satellite postgraduate courses and a symposium will be organized by these two societies on September 1 and September 5 .

The main topics of the ESPR meeting are: therapeutic interventions in immune-mediated diseases, connective tissue, energy metabolism, and circulation of the neonatal brain.

For information, contact: Gabriel Duc, University Hospital of Zürich, Frauenklinikstrasse 10, ZH-8091 Zürich, Tel. + 41125553 40, Telefax + 4112554442 . 